\title{
Forage value of native and introduced browse species in Tanzania
}

\author{
RASHID B.R. MSANGI AND LINDA H. HARDESTY
}

\begin{abstract}
At the time of research authors were graduate research assistant and assistant professor, Department of Natural Resource Sciences, Washington State University, Pullman, Wash. 99164-6410.
\end{abstract}

\begin{abstract}
The nutritional value of Leucaena leucocephala (Lam.) de Wit was compared with that of 3 browse species native to western Tanzania: Antidesma venosum Mey. \& Tul., Margaritaria discoides Baill., and Phyllanthus reticulatus Lodd. Foliage samples were collected monthly throughout the dry season from replicated sites on 3 different soil types and analyzed for crude protein, total ash, and in vitro dry matter digestibility. The crude protein content of $L$. leucocephala $(17.60-29.69 \%)$ was higher $(P<.05)$ than that of the native species (8.51-16.33\%) throughout the study. Phyllanthus reticulatus had the highest crude protein of the native species. Abscised leaves had only half the crude protein of green leaves of the same species. All species showed a significant increase in crude protein when new leaves appeared. $L$. leucocephala had as much or more ash (6.96-9.77\%) than the native species.

Margaritaria discoides was more $(P<.05)$ digestible (56.75$74.06 \%$ ) than all other species on all dates but one. The in vitro dry matter digestibility of green and abscised leaves of the same species did not differ $(P<.05)$ until July when green leaves of $M$. discoides, were more digestible. Soil type affected the in vitro dry matter digestibility of all species except $A$. venosum $(P<.05)$, but did not affect crude protein values. Both the native species and $L$. leucocephala can contribute significantly to meeting animal nutrient demands in the dry season.
\end{abstract}

Key Words: Miombo, silvopastoral, Leucaena, Antidesma, Margaritaria, Phyllanthus

Major constraints to increased livestock production in Tanzania include seasonal feed shortages, excessive stocking rates, and disease. The semiarid regions are important for livestock production because they are relatively disease free, although they suffer acute seasonal shortages of forage.

The authors gratefully acknowledge the financial support of the International Center for Research in Agroforestry, Nairobi, Kenya, and the International Program Development Office at Washington State University. Sincere thanks are also extended to Mark L. Nelson, Benjamin A. Zamora, Charles T. Gaskins, and Bruce Davitt for their advice and assistance.

Manuscript accepted 23 Feb. 1993.
Poor animal performance in the dry season is due to lack of protein, energy, minerals, carotene, and phosphorus (Le Houerou $1980 \mathrm{a}, \mathrm{McD}$ owell et al. 1983). The crude protein of mature grasses declines to $1-2 \%$ during the dry season; digestible protein and phosphorus are often less than $1 \mathrm{~g} / \mathrm{kg}$ dry matter (DM), calcium 1.5 to $3.0 \mathrm{~g} / \mathrm{kg} \mathrm{DM}$, and carotene less than $1 \mathrm{mg} / \mathrm{kg} \mathrm{DM}$ (Crowder and Chheda 1982, Le Houerou 1980b). Low levels of crude protein depress microbial activity in the rumen, reducing digestibility and intake (Minson and Milford 1967).

During the dry months, native browse plants have been reported to have 56-300, 1.5-2.5, and $2.5-20 \mathrm{~g} / \mathrm{kg} \mathrm{DM}$ of digestible protein, phosphorus, and calcium, respectively (Le Houerou 1980b). In central Tanzania, crude protein and $\mathrm{P}$ in $\mathrm{g} / \mathrm{kg}$ DM were found to be 23.89 and 0.24 in Baphia massaiensis, 22.06 and 0.29 in Combretum obvatum, 16.75 and .26 in Brachystegia spiciformis, and 18.63 and 0.30 in Afzelia quanzensis, respectively. High carotene contents were also noted in Albizia amara $(189 \mu \mathrm{g} / \mathrm{g}$ DM), Afzelia quanzensis (186 $\mu \mathrm{g} / \mathrm{g} \mathrm{DM}$ ), and Baphia massaiensis $(79 \mu \mathrm{g} / \mathrm{g}$ DM) (Lawton 1982). Species of Bascia, Cadaba and Maerua have on average $25 \%$ more protein than legumes, twice as high a silicafree mineral content, and nearly as much energy as legumes (Le Houerou 1980c).

There has been increasing interest in exotic browse species. Leucaena leucocephala is one of the most promising. However, the value of introduced species for animal production may be limited for many years due to lack of seeds and technical skills for establishment. Native trees and shrubs will continue to be an important source of browse for livestock, and one which is less subject to the potential ecological hazards of introduced species.

The objectives of this study were to: (1) identify important native browse species used by goats during the dry season in the woodlands of Western Tanzania; (2) compare the nutritive value of leaves of the 3 most important native browse species and leucaena during the dry season as an indicator of their relative potential feeding value for goats during the dry season; and (3) determine if soil type influences the nutritional value of any of the species studied. 


\section{Materials and Methods}

\section{Study Area}

This study was conducted at the Agricultural Research Institute in Tabora, located in the semiarid northcentral region of Tanzania. This region has an unimodal rainfall regime with a long, hot, dry season. During 1991, the study site received $1,019 \mathrm{~mm}$ of rain compared to a 10-year mean of $883 \mathrm{~mm}$. Temperatures ranged from a mean minimum of $17.8^{\circ} \mathrm{C}$ to a mean maximum of $28.8^{\circ} \mathrm{C}$. The 3 main soils are red sand on the upper slopes of the undulating plains, grey sand on the lower slopes, and black to grey clay (mbuga) in the lowlands. Published descriptions of these soils are not available. Soil types are recognizable by soil surface characteristics, topographic position, and the density and appearance of the vegetation.

All 3 sites support vegetation typical of the deciduous Miombo woodlands occurring throughout the southern interior of Africa. Dominant woody plants include species of Brachystegia, Julbernardia, and Isoberlina. Hyparrhenia dissoluta Nees ex Steud. is the dominant grass species.

\section{Selection of Native Browse Species}

Information from an ethnobotanical survey of multipurpose trees in the Tabora region (Karachi et al. 1991) was supplemented by observing 35 goats grazing the 1,858 ha study area and recording the frequency of selection of each species browsed. Every browse species was collected and identified at the herbarium at Kongwa Pasture Research Center. Antidesma venosum Mey. \& Tul., Margaritaria discoides Baill., and Phyllanthus reticulatus Lodd. were selected for further study based on their reported (Karachi et al. 1991) and observed importance as browse, and their widespread availability in the study area.

\section{Nutritive Value}

Samples of green and abscised foliage of each species were collected at monthly intervals during the dry season of 1991 from 3 replicated sites on each of 3 major soil types. Samples representing ingested forage were obtained by observing goats and harvesting material comparable to that being browsed. The same animals were used at each sampling date, and they continued to feed in the study area between sampling dates. At least 6 plants of each species in each replicate were sampled. Plant material was dried at $50^{\circ} \mathrm{C}$, ground in a Wiley mill to pass a $1-\mathrm{mm}$ screen, and stored in sealed bags. Leucaena was collected from established plots on each soil type at the same time and in the same manner as the native species.

Laboratory analyses were performed in duplicate. Crude protein was determined using a macro-Kjeldahl apparatus and total ash was estimated by burning samples in an ashing oven at $600^{\circ} \mathrm{C}$ for 2 hours. The in vitro dry matter digestibility analysis used the modified (Goering and Van Soest 1970) method of Tilley and Terry (1963). Four blanks served as controls. A forage of known in vitro value was included in duplicate with each of the 4 digestion runs to standardize results. No correction was needed as differences between the standards were extremely small. Rumen fluid was collected from a cow fed $6.8 \mathrm{~kg}$ of alfalfa (Medicago sativa L.) hay and $1 \mathrm{~kg}$ of concentrate daily. Rumen fluid was transported in a vacuum bottle for 10 minutes, filtered through cheesecloth, and distributed immediately to the prepared samples.

\section{Presence of Selected Browse Species in Goat Diets}

The presence of each species in goat diets during the study was determined using microhistological analysis of fecal samples. Sampling occurred at 2-month intervals from June through October of 1991. Feces were collected on 3 consecutive days from 7 animals browsing in the study area. Fecal samples were composited by animals and dates, mixed, sub-sampled to $10 \%$, and oven dried at $50^{\circ} \mathrm{C}$. In the laboratory, feces were broken down by agitation in a household type blender, washed in a 200-mesh screen, stained, and mounted on microscope slides (Davitt and Nelson 1980). Reference slides were prepared from fresh leaves of each species in the same manner as the feces.

A gridded lens eyepiece in the microscope was used to estimate the surface covered by each identifiable fragment. On each of the 4 slides prepared for each date, 25 fields/slide were located using a random table of coordinates, and the number of squares covered at 100x magnification was recorded for each plant species. Diet composition was expressed as the percentage that each species comprised of the total surface for all species recorded.

Prior to fecal collection, the availability of each species on each site was determined using 3 availability classes (abundant green forage within reach, present only in leaf litter, and not easily located as either green forage or litter). Leaf litter was collected from 3 quadrats of $0.5 \mathrm{~m}^{2}$, randomly located on each site at each date, and sorted to determine species composition.

\section{Statistical Methods}

Cochran's test was used to test the homogeneity of variances of

Table 1. A vailability of forage from native browse species and Leucaena leucocephala in Miombo woodland in the study area during the dry season of 1991 , including dry season phenology and growth form.

\begin{tabular}{|c|c|c|c|c|c|c|c|}
\hline \multirow[b]{2}{*}{ Species } & \multirow[b]{2}{*}{ Phenology' } & \multirow{2}{*}{$\begin{array}{c}\text { Growth } \\
\text { form }^{2}\end{array}$} & \multicolumn{5}{|c|}{1991} \\
\hline & & & Jun. & Jul. & Aug. & Sep. & Oct. \\
\hline & & & \multicolumn{5}{|c|}{$\ldots$} \\
\hline Antidesma venosum & $\mathrm{E}$ & $\mathbf{T}$ & + & + & + & + & + \\
\hline Brachystegia spiciformis & $\overline{\mathrm{D}}$ & $\mathbf{T}$ & + & * & * & + & + \\
\hline Dichrostachys cinerea & $\mathrm{E}$ & $\mathbf{T}$ & + & + & + & + & + \\
\hline Friesodielsia obovata & D & $\mathbf{S}$ & + & * & $*$ & * & + \\
\hline Hymenocardia acida & $\mathrm{E}$ & $\mathbf{S}$ & + & + & - & - & + \\
\hline Julbernardia globiflora & D & $\mathrm{T}$ & + & $*$ & $*$ & + & + \\
\hline Leucaena leucocephala & $\mathrm{E}$ & $\mathrm{T}$ & + & + & + & + & + \\
\hline Margaritaria discoides & $\mathrm{E}$ & $\mathbf{S}$ & + & + & - & + & + \\
\hline Phyllanthus reticulatus & $\bar{E}$ & $\mathbf{S}$ & + & + & + & + & + \\
\hline Sclerocarya bierrea & $\bar{D}$ & $\mathbf{T}$ & + & + & * & * & + \\
\hline Strynchnos coculoides & D & $\mathbf{S}$ & + & + & - & - & + \\
\hline Terminalia sericea & D & $\mathrm{T}$ & + & + & - & - & + \\
\hline Vitex mombassae & D & $\mathbf{T}$ & + & + & - & - & + \\
\hline
\end{tabular}

'D-Deciduous, E-Evergreen

2T-Tree, S-Shrub

${ }^{3+}$ Abundant green foliage available, *Available only as litter, - Scarce as either green foliage or litter. 
means to be compared by analysis of variance (Guenther 1964). A 2 factor experiment with repeated measures of time was used to compare means of chemical composition, total amount of leaf litter, and species composition of leaf litter (Freund and Littell 1981). Lacking replicates of leucaena, replication was excluded when leucaena was compared with the native species. A complete randomized block design was used to evaluate species frequency in fecal samples. The relationship between crude protein and in vitro dry matter digestibility of each species was established by regression. Significance was established by LSD at $5 \%$.

\section{Results and Discussion}

Throughout this section, only differences significant at $P \leq 0.05$ are discussed. Thirteen major browse species provided forage for goats during this study (Table 1). By the middle of the dry season (August), herbaceous forage was only available as dry, cured material. Phyllanthus reticulatus, Dichrostachys cinerea Wight \& Arn. and $M$. discoides produced new leaves in late September, apparently stimulated by increasing temperatures. Rain in October stimulated new growth of woody plants and grasses, improving forage availability.

Goats were frequently observed eating leaf litter, particularly in the mid-dry season. The amount of litter available was relatively constant throughout the study, with a season-long mean of 1.37 metric tons/ha. None of the species studied contributed substantially to the leaf litter, but $M$. discoides and $A$. venosum were present in the leaf litter throughout the study.

\section{Diet Composition}

Antidesma venosum, Margaritaria discoides, and Phyllanthus reticulatus consistently provided the bulk of the browse in goats' diets during the dry season (Table 2). Phyllanthus reticulatus was

Table 2. Percent contribution of individual browse species by date ${ }^{1}$, and by species and forage class at each date, to goat diets during the dry season.

\begin{tabular}{|c|c|c|c|c|}
\hline \multirow[b]{2}{*}{ Species } & \multicolumn{3}{|c|}{1991 Sampling periods } & \multirow{2}{*}{$\begin{array}{c}\text { Standard } \\
\text { error (date) }\end{array}$} \\
\hline & June & Aug. & Oct. & \\
\hline Antidesma venosum & \multicolumn{4}{|c|}{$\ldots \ldots$ of diet $) \ldots \ldots$} \\
\hline $\begin{array}{l}\text { Brachystegia spici- } \\
\quad \text { formis }\end{array}$ & $0.00^{\mathrm{d} A}$ & $1.91^{\text {cdeA }}$ & $3.43^{\text {cdeA }}$ & 0.97 \\
\hline Dichrostachys cinerea & $1.64^{\mathrm{dA}}$ & $0.77^{\mathrm{edA}}$ & $1.52^{\mathrm{deA}}$ & 0.63 \\
\hline Grewia bicolor & $0.00^{\mathrm{dA}}$ & $1.91^{\text {cdeA }}$ & $2.67^{\text {deA }}$ & 1.05 \\
\hline Hymenocardia acida & $4.51^{\mathrm{cbA}}$ & $4.59^{\mathrm{cbdA}}$ & $3.43^{\text {cdeA }}$ & 2.04 \\
\hline Julbernardia globiflora & $4.92^{\mathrm{cbA}}$ & $1.53^{\text {cdeA }}$ & $4.57^{\text {bodA }}$ & 2.34 \\
\hline Margaritaria discoides & $6.15^{\mathrm{bB}}$ & $11.85^{\mathrm{abA}}$ & $3.43^{\text {cdeB }}$ & 0.81 \\
\hline Vitex mombassae & $0.00^{\mathrm{dA}}$ & $0.00^{\mathrm{eA}}$ & $0.38^{\mathrm{EA}}$ & 0.22 \\
\hline Phyllanthus reticulatus & $26.23^{\mathrm{aA}}$ & $14.53^{\mathrm{aA}}$ & $20.95^{\mathrm{aA}}$ & 6.14 \\
\hline Strynchnos coculoides & $2.87^{\mathrm{cbdA}}$ & $2.10^{\text {odeA }}$ & $1.14^{\text {deA }}$ & 1.38 \\
\hline Unidentified shrubs & $5.74^{\mathrm{cbAB}}$ & $12.24^{\mathrm{abA}}$ & $0.00^{\mathrm{eA}}$ & 2.35 \\
\hline Total browse & 55.13 & 61.56 & 51.42 & - \\
\hline Total grass & 33.60 & 24.67 & 30.10 & - \\
\hline Unknown tricome & $5.33^{\mathrm{cbA}}$ & $6.50^{\mathrm{abcA}}$ & $6.10^{\mathrm{cbA}}$ & 1.78 \\
\hline Unknown voucher & $5.94^{\mathrm{bB}}$ & $7.27^{\mathrm{abcA}}$ & $12.38^{\mathrm{abA}}$ & 3.33 \\
\hline $\begin{array}{l}\text { Standard error } \\
\text { (species) }\end{array}$ & 0.18 & 0.17 & 0.16 & \\
\hline
\end{tabular}

Means in the same column followed by same lowercase superscripts (a,b) or in same row followed by same uppercase superscripts $(A, B)$ are not significantly different at $P<.05$.

'Analysis performed on log transformed data.

the most frequent browse plant in diets throughout the study and goats consumed relatively constant amounts of it (Table 2). Consumption of $A$. venosum increased during the latter half of the dry season while $M$. discoides consumption was highest in August.

Brachystegia spiciformis and Julbernardia globiflora formed a major component of the vegetation but contributed relatively little to the goats' diets. These species lose their leaves early in the dry season and are often out of reach of the animals when green. Goats consumed almost constant small amounts of Hymenocardia acida Tul. and Strynchnos coculoides Baker.

Browse consumption increased as grass consumption decreased in August when green grass was not available (Fig. 1). Other researchers have reported that grass use by goats increased with

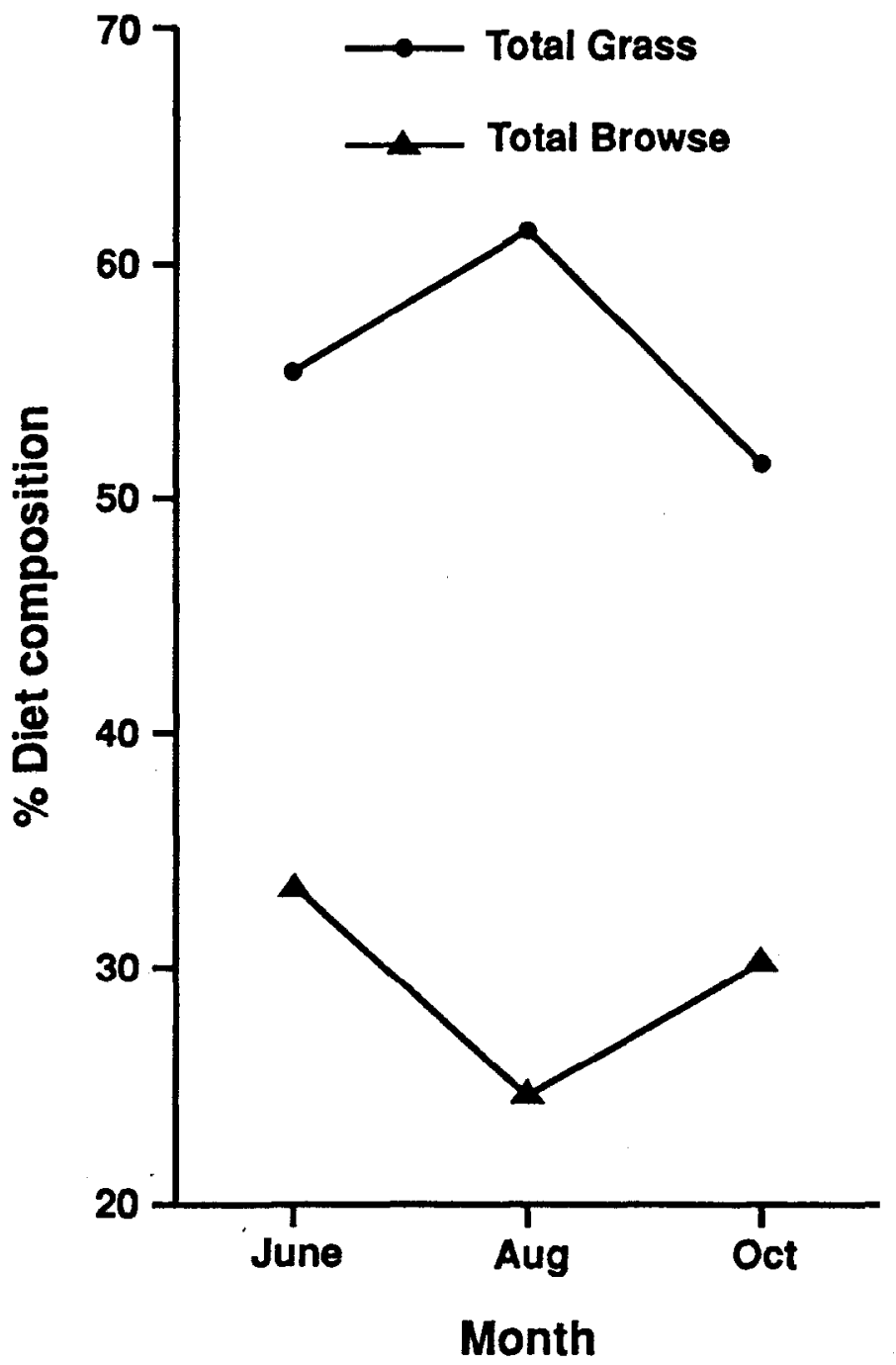

Fig. 1. Percent of total browse and total grass in the diet of goats grazing Miombo woodlands during the dry season of 1991 (does not total to 100 because of unknowns).

availability (Bryant et al. 1979). Our results are consistent with studies in semiarid regions of Kenya and Australia (Wilson 1957, Wilson et al. 1975, Wilson et al. 1976).

\section{Crude Protein}

Leucaena consistently had higher crude protein values than the native species (Table 3 ). Among native species, $P$. reticulatus had the highest crude protein values. The crude protein levels of all species except $M$. discoides increased following the October rain. Margaritaria discoides showed an earlier increase in crude protein that persisted into October (Table 3).

Changes in crude protein appeared to be related to the phenological stage of the plant. Phyllanthus reticulatus and $M$. discoides initiated growth in late September at which time crude protein concentrations increased. The crude protein concentration of $A$. venosum increased consistently from June through August, de- 
Table 3. Percent crude protein, ash content and in-vitro dry matter digestibility of green leaves of 3 native Miombo species and Leucaena leucocephala, by date and species at each date.

\begin{tabular}{|c|c|c|c|c|c|c|}
\hline \multirow[b]{2}{*}{ Species } & \multicolumn{5}{|c|}{1991 Sampling periods } & \multirow{2}{*}{$\begin{array}{c}\text { Standard error } \\
\text { (date) }\end{array}$} \\
\hline & June & July & Aug. & Sep. & Oct. & \\
\hline & 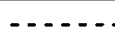 & 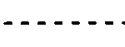 & $--(\% \mathrm{D}$ & -- & $-\ldots$ & \\
\hline $\begin{array}{l}\text { Crude protein } \\
\text { Antidesma venosum } \\
\text { Margaritaria discoides } \\
\text { Phyllanthus reticulatus } \\
\text { Leucaena leucocephala } \\
\text { Standard error (species) }\end{array}$ & $\begin{array}{c}9.38^{\mathrm{cC}} \\
9.17^{\mathrm{bC}} \\
12.19^{\mathrm{dB}} \\
21.34^{\mathrm{bA}} \\
0.01\end{array}$ & $\begin{array}{l}9.92^{\mathrm{cbCB}} \\
8.51^{\mathrm{bC}} \\
13.45^{\mathrm{cB}} \\
20.92^{\mathrm{bA}} \\
1.22\end{array}$ & $\begin{array}{c}10.77^{\mathrm{bC}} \\
8.53^{\mathrm{bC}} \\
14.27^{\mathrm{cbB}} \\
17.60^{\mathrm{bA}} \\
0.81\end{array}$ & $\begin{array}{c}9.24^{\mathrm{eC}} \\
13.96^{\mathrm{aB}} \\
15.07^{\mathrm{bAB}} \\
18.01^{\mathrm{bA}} \\
1.16\end{array}$ & $\begin{array}{c}14.04^{\mathrm{aC}} \\
14.59^{\mathrm{aC}} \\
16.33^{\mathrm{aB}} \\
29.69^{\mathrm{aA}} \\
0.37\end{array}$ & $\begin{array}{l}0.41 \\
0.28 \\
0.60 \\
1.26\end{array}$ \\
\hline $\begin{array}{l}\text { Ash content } \\
\text { Antidesma venosum } \\
\text { Margaritaria discoides } \\
\text { Phyllanthus reticulatus } \\
\text { Leucaena leucocephala } \\
\text { Standard error (species) }\end{array}$ & $\begin{array}{l}7.44^{\mathrm{abB}} \\
6.96^{\mathrm{aB}} \\
7.05^{\mathrm{abB}} \\
9.63^{\mathrm{aA}} \\
0.28\end{array}$ & $\begin{array}{l}7.71^{\mathrm{aA}} \\
7.54^{\mathrm{aA}} \\
6.89^{\mathrm{abA}} \\
8.68^{\mathrm{aA}} \\
0.52\end{array}$ & $\begin{array}{l}6.83^{\mathrm{bB}} \\
7.00^{\mathrm{aB}} \\
7.18^{\mathrm{aB}} \\
9.77^{\mathrm{AA}} \\
0.52\end{array}$ & $\begin{array}{l}6.77^{\mathrm{bB}} \\
6.57^{\mathrm{aB}} \\
6.25^{\mathrm{bB}} \\
8.98^{\mathrm{aA}} \\
0.50\end{array}$ & $\begin{array}{l}7.59^{\mathrm{aA}} \\
6.90^{\mathrm{aA}} \\
7.10^{\mathrm{abA}} \\
6.96^{\mathrm{bA}} \\
0.27\end{array}$ & $\begin{array}{l}0.19 \\
0.36 \\
0.32 \\
0.13\end{array}$ \\
\hline $\begin{array}{l}\text { In-vitro dry matter digestib } \\
\text { Antidesma venosum } \\
\text { Margaritaria discoides } \\
\text { Phyllanthus reticulatus } \\
\text { Leucaena leucocephala } \\
\text { Standard error (species) }\end{array}$ & $\begin{array}{c}21.09^{\mathrm{cC}} \\
58.92^{\mathrm{cA}} \\
48.02^{\mathrm{cB}} \\
52.93^{\mathrm{bB}} \\
1.49\end{array}$ & $\begin{array}{l}20.43^{\mathrm{cB}} \\
54.35^{\mathrm{aA}} \\
54.35^{\mathrm{aA}} \\
56.56^{\mathrm{bA}} \\
1.67\end{array}$ & $\begin{array}{c}22.51^{\mathrm{cbC}} \\
49.24^{\mathrm{cbB}} \\
49.24^{\mathrm{cbB}} \\
54.09^{\mathrm{bB}} \\
1.48\end{array}$ & $\begin{array}{l}24.49^{\mathrm{bC}} \\
52.60^{\mathrm{abC}} \\
52.60^{\mathrm{abB}} \\
55.86^{\mathrm{bB}} \\
1.60\end{array}$ & $\begin{array}{l}28.37^{\mathrm{aD}} \\
0.77 \\
52.00^{\mathrm{abC}} \\
64.77^{\mathrm{aB}} \\
1.32\end{array}$ & $\begin{array}{l}0.87 \\
0.77 \\
1.91\end{array}$ \\
\hline
\end{tabular}

Means in the same row followed by same lowercase superscripts $(a, b)$, or in the same column followed by same uppercase superscript (A,B) are not significantly different at $P<.05$.

$\mathrm{l}_{\mathbf{n}}=\mathbf{9}$ and 3 for native species and leucaena, respectively.

creased in September and increased in October. The low levels of crude protein during the early part of the dry season were probably due to high proportions of mature leaves in the samples. As the plants mature, crude protein concentration declines due to increases in structural carbohydrates (Van Soest 1982).

Our crude protein data are similar to those for Miombo species in Zambia and Tanzania (Rees 1974, Lawton 1982). The crude protein values for leucaena compared fairly well with the results of other studies in similar environments (Jones 1979, Keogham 1980 , NRC 1984, Skerman 1977). In Kenya, Child et al. (1982) found that new leucaena leaves had higher crude protein than mature leaves. Leucaena's higher crude protein values may be due, at least in part, to fact that none of the native species studied are legumes.

The crude protein concentrations of abscised leaves of $A$. venosum and $M$. discoides in leaf litter remained constant and equal throughout the study (Table 4). Green leaves had approximately twice as much crude protein as abscised leaves of the same species.

Nitrogen loss through leaching and decomposition may contribute to the low level of crude protein observed in abscised leaves (Tukey 1970). In addition, foliar nitrogen declines prior to leaf abscission when protein in older leaves is hydrolyzed and its breakdown products are translocated to the other plant parts (Grigal et al. 1976, Mayer and Splittstoesser 1969).

Soil type did not affect the crude protein concentration of any of the 4 species.

\section{Total Ash Content}

The ash content of leucaena was equal to or exceeded that of the native species on all dates (Table 3). Ash content varied with date and soil type for all species except $A$. venosum. (Tables 3 and 5).

Our data are consistent with values reported by McLeod (1973) in Australia, and unpublished Tanzanian data. However, Dougal et al. (1964) reported a considerably higher average, $11.73 \%$ for nonleguminous browse species in East Africa. The ash content of leucaena in this study is comparable with some other studies (Hill 1971, Singh and Mudgal 1967, Upadhyaya et al. 1974), but substantially lower than the $11 \%$ reported by Thomas and Addy (1977) in Malawi and the NRC (1984). Differences in ash content may
Table 4. Percent crude protein, ash content, and in-vitro dry matter digestibility of green and abscised leaves of Antidesma venosum and Margaritaria discoides at each date.

\begin{tabular}{|c|c|c|c|c|}
\hline \multirow[b]{2}{*}{ Material } & \multicolumn{4}{|c|}{1991 Collection periods } \\
\hline & June & Jul. & Aug. & Sep. \\
\hline $\begin{array}{l}\text { Crude protein } \\
\text { Antidesma venos } \\
\text { Green leaves } \\
\text { Abscised leaves } \\
\text { Standard error }\end{array}$ & $\begin{array}{l}9.38^{\mathrm{a}} \\
5.23^{\mathrm{b}} \\
0.23\end{array}$ & $\begin{array}{l}9.92^{\mathrm{a}} \\
5.17^{\mathrm{b}} \\
0.39\end{array}$ & $\begin{array}{c}10.77^{\mathrm{a}} \\
5.13^{\mathrm{b}} \\
0.27\end{array}$ & $\begin{array}{l}9.24^{\mathrm{a}} \\
5.22^{\mathrm{b}} \\
0.27\end{array}$ \\
\hline $\begin{array}{l}\text { Margaritaria disc } \\
\text { Green leaves } \\
\text { Abscised leaves } \\
\text { Standard error }\end{array}$ & $\begin{array}{l}9.17^{\mathrm{a}} \\
5.72^{\mathrm{b}} \\
0.12\end{array}$ & $\begin{array}{l}8.51^{\mathrm{a}} \\
5.49^{\mathrm{b}} \\
0.07\end{array}$ & $\begin{array}{l}8.53^{a} \\
5.40^{b} \\
0.12\end{array}$ & $\begin{array}{c}13.96^{\mathrm{a}} \\
5.43^{\mathrm{b}} \\
0.40\end{array}$ \\
\hline $\begin{array}{l}\text { Asb Content } \\
\text { Antidesma venos } \\
\text { Green leaves } \\
\text { Abscised leaves } \\
\text { Standard error }\end{array}$ & $\begin{array}{c}7.43^{\mathrm{b}} \\
12.65^{\mathrm{a}} \\
0.28\end{array}$ & $\begin{array}{c}7.71^{\mathrm{b}} \\
13.19^{\mathrm{a}} \\
0.24\end{array}$ & $\begin{array}{c}6.83^{\mathrm{b}} \\
13.16^{\mathrm{a}} \\
0.74\end{array}$ & $\begin{array}{c}6.77^{\mathrm{b}} \\
14.80^{\mathrm{a}} \\
0.16\end{array}$ \\
\hline $\begin{array}{c}\text { Margaritaria disc } \\
\text { Green leaves } \\
\text { Abscised leaves } \\
\text { Standard error }\end{array}$ & $\begin{array}{l}6.96^{\mathrm{a}} \\
7.26^{\mathrm{a}} \\
0.37\end{array}$ & $\begin{array}{l}7.54^{\mathrm{a}} \\
8.18^{\mathrm{a}} \\
0.37\end{array}$ & $\begin{array}{l}7.00^{\mathrm{a}} \\
8.10^{\mathrm{a}} \\
0.33\end{array}$ & $\begin{array}{l}6.57^{\mathrm{b}} \\
7.61^{\mathrm{a}} \\
0.11\end{array}$ \\
\hline $\begin{array}{c}\text { In-vitro dry matte } \\
\text { Antidesma venos } \\
\text { Green leaves } \\
\text { Abscised leaves } \\
\text { Standard error }\end{array}$ & $\begin{array}{c}\text { estibility } \\
21.69^{\mathrm{a}} \\
21.57^{\mathrm{a}} \\
1.40\end{array}$ & $\begin{array}{c}20.43^{\mathrm{a}} \\
20.83^{\mathrm{a}} \\
1.39\end{array}$ & $\begin{array}{c}22.51^{\mathrm{n}} \\
21.18^{\mathrm{a}} \\
1.55\end{array}$ & $\begin{array}{c}24.49^{\mathrm{a}} \\
23.30^{\mathrm{a}} \\
1.11\end{array}$ \\
\hline $\begin{array}{l}\text { Margaritaria disc } \\
\text { Green leaves } \\
\text { Abscised leaves } \\
\text { Standard error }\end{array}$ & $\begin{array}{c}58.92^{\mathrm{a}} \\
48.92^{\mathrm{a}} \\
2.52\end{array}$ & $\begin{array}{c}56.75^{\mathrm{a}} \\
49.13^{\mathrm{a}} \\
1.37\end{array}$ & $\begin{array}{c}64.17^{\mathrm{a}} \\
41.22^{\mathrm{b}} \\
2.24\end{array}$ & $\begin{array}{c}65.92^{\mathrm{a}} \\
48.11^{\mathrm{b}} \\
1.01\end{array}$ \\
\hline
\end{tabular}

Means in the same column for each species followed by same superscript $(a, b)$ are not significantly different at $P<.05$.

relate to differences in stage of maturity, and soil chemistry (McDowell et al. 1983, Reid and Horvath 1980).

The higher ash content of abscised leaves (Table 4) is an anomaly 
because as leaves mature, their mineral content generally declines due to dilution and translocation (McDowell et al. 1983). These values probably reflect soil or dust contamination of leaf litter.

\section{In vitro Dry Matter Digestibility}

Margaritaria discoides was more digestible than the other 3 species at all dates except July, when it was similar to P. reticulatus and leucaena (Table 3). From June through September, $P$. reticulatus and leucaena were equally digestible, but by October, leucaena was more digestible. All species except $P$. reticulatus showed an increase in digestibility following the October rain.

In Australia, McLeod (1973) found that $68 \%$ of the browse species studied throughout the year had digestibilities less than $50 \%$. The digestibility of cattle browse in Ghana varied from 54 to 70\% (Rose-Innes and Mabey 1964). In the present study, the digestibility of leucaena leaves varied from 53 to $65 \%$, consistent with most values reported in the literature (Hill 1971, Jones 1979, NRC 1984), but lower than the 65 to $87 \%$ reported by Skerman (1977). Studies that compare the feeding values of leucaena with native species are limited. Contrary to our results, Bamualim et al. (1980) found that the digestibility of leucaena was generally higher than that of a number of other species.

The digestibility of abscised leaves of $A$. venosum did not differ across sampling periods. During June and July the in vitro dry matter digestibility of abscised leaves of $M$. discoides was higher than in August and September. Abscised leaves of $M$. discoides were consistently more digestible than $A$. venosum at each sampling date.

No differences in digestibility were observed between green and abscised leaves of $A$. venosum at any date (Table 4). The digestibility of green and abscised leaves of $M$. discoides did not differ except in August and September, when green leaves were more digestible. This is not unexpected because with advancing maturity the proportion of structural carbohydrates in the plant increases, while nutrient concentration and digestibility decrease (Kilcher 1981, Minson 1971, Van Soest 1982). Furthermore, abscised leaves typically had crude protein concentrations below $6 \%$, while crude protein levels below 7\% depress digestbility due to lack of nitrogen (Milford and Minson 1966). A significant linear relationship $\left(r^{2}>.60\right)$ between crude protein and in vitro dry matter digestibility existed for all species except $P$. reticulatus $\left(r^{2}=0.21\right)$.

Soil type affected the digestibility of all the materials examined except green $P$. reticulatus and leucaena (Table 5). The digestibility of $A$. venosum was lower on grey soils while $M$. discoides from red soil sites was most digestible.

Our digestibility values are probably affected by use of rumen liquor from a cow maintained on alfalfa. In vitro procedures tend to underestimate the digestibility of browse when donor animal rations do not contain browse (Sidahmed et al. 1981). Further, the in vitro digestibility of browse approximates in vivo digestibility more closely when a deer (browser) rather than a cow (grazer) is fed alfalfa (Robbins et al. 1975). In an earlier analysis using rumen liquor from goats maintained on browse in Tanzania, we found that dry matter digestibility was as much as $26 \%, 24 \%, 16 \%$, and $18 \%$ greater than when cow rumen liquor was used for $A$. venosum, $P$. reticulatus, $M$. discoides and leucaena, respectively.

\section{Conclusions}

Browse, particularly the 3 native species selected for study, was the most important component of goats' diets throughout the dry season. Browse and grass were complementary, with browse consumption increasing as grass consumption decreased in the middle of the dry season. It appeared that crude protein content and availability of individual species influenced selection by goats.

Leucaena was superior to the native browse species in crude
Table 5. Ash content and in-vitro dry matter digestibility of native Miombo browse species and Leucaena leucocephala from 3 soil types (all dates averaged).

\begin{tabular}{|c|c|c|c|c|}
\hline \multirow[b]{2}{*}{ Species } & \multicolumn{3}{|c|}{ Soil type } & \multirow{2}{*}{$\begin{array}{l}\text { Standard } \\
\text { error }\end{array}$} \\
\hline & Red & Mbuga & Grey & \\
\hline & $\ldots$ & $\ldots(0)$ & - - - & \\
\hline $\begin{array}{l}\text { Ash content } \\
\text { Antidesma venosum } \\
\text { Margaritaria discoides } \\
\text { Phyllanthus reticulatus } \\
\text { Leucaena leucocephala }\end{array}$ & $\begin{array}{l}7.22^{\mathrm{a}} \\
6.41^{\mathrm{b}} \\
6.30^{\mathrm{b}} \\
9.52^{\mathrm{a}}\end{array}$ & $\begin{array}{l}7.11^{\mathrm{a}} \\
7.24^{\mathrm{a}} \\
7.12^{\mathrm{a}} \\
8.15^{\mathrm{b}}\end{array}$ & $\begin{array}{l}7.45^{\mathrm{a}} \\
7.35^{\mathrm{a}} \\
7.26^{\mathrm{a}} \\
8.74^{\mathrm{ab}}\end{array}$ & $\begin{array}{l}0.38 \\
1.16 \\
1.15 \\
0.89\end{array}$ \\
\hline $\begin{array}{l}\text { In-vitro dry matter digesti } \\
\text { Antidesma venosum } \\
\text { Margaritaria discoides } \\
\text { Phyllanthus reticulatus } \\
\text { Leucaena leucocephala }\end{array}$ & $\begin{array}{l}\text { ibility } \\
23.51^{\mathrm{a}} \\
65.53^{\mathrm{a}} \\
50.41^{\mathrm{a}} \\
57.57^{\mathrm{a}}\end{array}$ & $\begin{array}{l}24.87^{\mathrm{a}} \\
63.44^{\mathrm{b}} \\
51.04^{\mathrm{a}} \\
55.00^{\mathrm{a}}\end{array}$ & $\begin{array}{l}21.77^{\mathrm{b}} \\
62.92^{\mathrm{b}} \\
52.28^{\mathrm{a}} \\
57.95^{\mathrm{a}}\end{array}$ & $\begin{array}{l}3.46 \\
1.73 \\
2.12 \\
2.07\end{array}$ \\
\hline
\end{tabular}

Means in the same row followed by same superscript $(a, b)$ are not significantly different at $P<.05$.

protein content. Green leaves of all 4 species nonetheless maintained crude protein levels in excess of the $8.4 \%$ goats need for maintenance and production (NRC 1981). This may be misleading, however, because not all protein is digestible and antiquality factors may further reduce available protein below what crude protein concentration imply.

The dry matter digestibility of leucaena was significantly lower than that of $\boldsymbol{M}$. discoides and usually similar to that of $P$. reticulatus, suggesting these species may have similar potential as feed sources during the dry season. However, more research needs to be conducted to better understand seasonal variations in the nutritional value of various browse species and the potential effects of any antiquality factors on dry matter intake and digestibility. The influence of soil type on nutritional properties should also be considered.

Native browse species in the Miombo woodlands are most important to livestock just prior to the onset of the first rains. At this time most woody species produce very digestible young leaves high in crude protein while herbaceous vegetation is scarce and of poor quality. To insure adequate dry season nutrition, leucaena or other native or introduced evergreen trees and shrubs might be planted and used as a fodder bank earlier in the dry season. Alternatively, leaves of native browse species might be harvested and stored before reaching maturity.

Currently, adequate animal nutrition during the dry season depends upon including native browse species in the grazing management system. Long term strategies for establishment of $L$. leucocephala and/or other improved species should be formulated in association with proper management of the native species.

\section{Literature Cited}

Bamualim, A., R.J. Jones, and R.M. Murray. 1980. Nutritive value of tropical browse legumes in the dry season. Proc. Austr. Soc. Anim. Prod. 13:229-232.

Bryant, F.C., Kothmann, M.M., and L.B. Merrill. 1979. Diets of sheep, Angora goats, Spanish goats and white-tailed deer under excellent range conditions. J. Range Manage. 32:412-417.

Child, R.D., J.N. Nyuki, R.M. Hansen, and D.L. Whittington. 1982. Digestibility and protein content of Leucaena leucocephala. E. Afr. Agr. For. J. 48:32-34.

Crowder, L.V., and H.R. Chheda. 1982. Tropical grassland hushandry, 1st ed., Longman Inc., N.Y.

Davitt, B.B., and J.R. Nelson. 1980. A method of preparing plant epidermal tissue for use in fecal analysis. Circ. 0628 Agr. Res. Center, Washington State Univ., Pullman. 
Dougal, H.W., V.M. Drysdale, and P.E. Glover. 1964. The chemical composition of Kenya browse and pasture herbage. E. Afr. Wildl. J. 2:82-125.

Freund, R.J., and R.C. Littell. 1981. SAS series in statistical application: A guide to the ANOVA and GLM procedures. SAS Institute Inc., Cary, N.C.

Goering, H.K., and P.J. Van Soest. 1970. Forage fiber analyses (apparatus, reagents, procedures, and some applications). USDA Handb. 379, Washington, D.C.

Grigal, D.F., L.F. Ohmann, and R.B. Brander. 1976. Seasonal dynamics of tall shrubs in Northern Minnesota: Biomass and nutrient elements changes. Forest. Sci. 22:195-207.

Guenther, W.C. 1964. Analysis of variance. Prentice-Hall, Inc., Englewood. Cliffs, N.J.

Hill, G.D. 1971. Leucaena leucocephala for pasture in the tropics. Herb. Abstr. 41:111-119.

Jones, R.J. 1979. The value of Leucaena leucocephala as a feed for ruminants in the tropics. World Animal Rev. 31:13-23.

Karachi, M., C.K. Ruffo, N.M. Lema, and S. Minae. 1991. Use of multipurpose trees in Western Tanzania: Results of an ethnobotanical survey of multipurpose trees in the Tabora region. Agrofor. Res. Networks Africa (AFRENA). Rep. 40. Nairobi, Kenya.

Keogham, J.M. 1980. Adaptable and productive forage legumes and grasses for more intensive small ruminant livestock systems in the Caribbean. Trop. Anim. Prod. 5:8-14.

Kilcher, M.R. 1981. Plant development, stage of maturity, and nutrient composition. J. Range Manage. 34:363-364.

Lawton, R.M. 1982. Browse in Miombo woodland, p. 25-31. In: H.N. Le Houerou (ed.), Proc. Int. Symp. on Browse in Africa. Int. Livestock Centre for Africa (ILCA)., Addis Ababa, Ethiopia.

Le Houerou, H.N. 1980a. Background and justification, p. 3. In: H.N. Le Houerou (ed.), Proc. Int. Symp. on Browse in Africa. Int. Livestock Centre for Africa (ILCA), Addis Ababa, Ethiopia.

Le Houerou, H.N. 1980b. The role of browse in the management of natural grazing lands, p. 329-338. In: H.N. Le Houerou (ed.), Proc. Int. Symp. on Browse in Africa. Int. Livestock Centre for Africa (ILCA)., Addis Ababa, Ethiopia.

Le Houerou, H.N. 1980c. Chemical composition and nutritive value of browse in tropical West Africa, p. 261-289. In: H.N. Le Houerou (ed.) Proc. Int. Symp. on Browse in Africa. Int. Livestock Centre for Africa (ILCA)., Addis Ababa, Ethiopia.

Mayer, Jr., M.M., and W.E. Splittstoesser. 1969. The utilization of carbohydrate and nitrogen reserves in the spring growth of lilac. Plant Physiol. 22:870-879.

McDowell, L.R., J.H. Conrad, G.L. Ellis, and J.K. Loosli. 1983. Minerals for grazing ruminants in the tropical regions. Bull., Dep. Anim. Sci. Univ. Florida, Gainesville, Fla.

McLeod, M.N. 1973. The digestibility and the nitrogen, phosphorus, and ash content of the leaves of some Australian trees and shrubs. Aust. $J$. Exp. Agr. and Anim. Husb. 13:245-250.

Milford, R., and D.J. Minson. 1966. The feeding value of tropical pastures, p. 106-114. In: W. Davies and C.L. Skidmore (eds). Tropical pastures. Faber and Faber. London.
Minson, D.J. 1971. The nutritive value of tropical pastures. J. Aust. Inst. Agr. Sci. 37:255-263.

Minson, D.J., and R. Milford. 1967. The voluntary intake and digestibility of diets containing different proportions of legume and mature pangola grass (Digitaria decumbens). Aust. J. Exp. Agr. Anim. Husb. 7:546-551.

National Research Council (NRC). 1981. Nutrient requirements of goats: angora, dairy, and meat goats in temperate and tropical countries. National Academy Press, Washington, D.C.

National Research Council (NRC). 1984. Leucaena: promising forage and tree crop for the tropics, 2nd ed. National Academy Press, Washington, DC.

Rees, W.A. 1974. Preliminary studies into bush utilization by cattle in Zambia. J. Appl. Ecol. 11:207-214.

Reid, R.L., and D.J. Horvath. 1980. Soil chemistry and mineral problems in farm livestock: A review. Anim. Feed Sci. Tech. 5:95-167.

Robbins, C.T., P.J. Van Soest, W.W. Mautx, and A.N. Moen. 1975. Feed analysis and digestion with reference to white tailed deer. J. Wildl. Manage. 39:67-69.

Rose-Innes, R., and G.L. Mabey. 1964. Studies on browse plants in Ghana II. Digestibility: (a) digestibility of Griffonia simplicifolia from the Accra plains, using local cattle as experimental animals. Emp. J. Exp. Agr. 32:125-130.

Sidahmed, A.E., J.G. Morris, L.J. Koong, and S.R. Rodesevich. 1981. Contribution of mixtures of three chaparral shrubs to the protein and energy requirements of Spanish goats. J. Anim. Sci. 53:1391.

Singh, H.K., and V.D. Mudgal. 1967. Chemical composition and nutritive value of Leucaena glauca. Indian J. Dairy Sci. 20:191-195.

Skerman, D.J. 1977. Tropical forage legumes. Plant production and protection series, No. 2. FAO, Rome.

Thomas, D., and B.L. Addy. 1977. Tropical pasture legumes and animal production in Malawi. World Rev. Animal Prod. 13:47-52.

Tilley, J.M.A., and R.A. Terry. 1963. A two stage technique for the in-vitro digestion of forage crops. J. Brit. Grassl. Soc. 18:104-111.

Tukey, H.B. Jr. 1970. Decomposition of litter on the soil surface, p. 611-632. In: C.H. Dickinson and G.L.F. Pugh (eds). Biology of plant litter decomposition. Vol. 2. Academic Press, London.

Upadhyaya, V.S., A. Rekib, and P.S. Pathak. 1974. Nutritive value of Leucaena leucocephala. Indian J. Dairy Sci. 51:534-537.

Van Soest, P.J. 1982. Nutritional ecology of the ruminants. O \& B Books, Corvallis, Ore.

Wilson, A.D., J.H. Leigh, N.L. Hindley, and W.E. Mulham. 1975. Comparison of the diets of goats and sheep on a Casuarina cristataHeterodendrum oleifolium woodland community in Western New South Wales. Aust. J. Exp. Agr. and Anim. Husb. 15:45-53.

Wilson, A.D., W.E. Mulham, and J.H. Leigh. 1976. A note on the effects of browsing by feral goats on a Belah (Casuarina cristata)-Rosewood (Heterodendrum oleifolium) woodland. Aust. Rangeland J. 1:7-12

Wilson, P.H. 1957. Studies on the browsing and reproduction behavior of the East African dwarf goats. E. African Agr. J. 23:138-147. 